\title{
UI EFEK LARVASIDA EKSTRAK DAUN GAMAL (Gliricida sepium) TERHADAP LARVA NYAMUK Aedes aegypti
}

\author{
Effect of Larvicidal Gamal Leaf (Gliricidia sepium) Against Aedes aegypti Larvae
}

\section{Rundito ${ }^{1 *}$ \\ Dody Novrial ${ }^{2}$ \\ Eman Sutrisna ${ }^{3}$}

\author{
*I Program Pascasariana \\ Magister Ilmu Biomedis, \\ Fakultas Kedokteran, \\ Universitas Jendral Soedirman, \\ Jalan Dr. Gumbreg Nomor I, \\ Mersi, Purwokerto, Banyumas, \\ Jawa Tengah, Indonesia \\ 2 Fakultas Kedokteran, \\ Universitas Jendral Soedirman, \\ Jalan Dr. Gumbreg Nomor I, \\ Mersi, Purwokerto, Banyumas, \\ Jawa Tengah, Indonesia \\ 3 Fakultas Kedokteran, \\ Universitas Jendral Soedirman, \\ Jalan Dr. Gumbreg Nomor I, \\ Mersi, Purwokerto, Banyumas, \\ Jawa Tengah \\ *email: prundito@yahoo.co.id
}

Kata Kunci:

Aedes aegypti

Gamal

Gliricidia sepium

$\mathrm{LC}_{50}$

$\mathrm{LC}_{90}$

\author{
Keywords: \\ Aedes aegypti \\ Gamal \\ Gliricidia sepium \\ $\mathrm{LC}_{50}$ \\ $\mathrm{LC}_{90}$
}

\begin{abstract}
Abstrak
Daun Gamal (Gliricidia sepium) selain digunakan sebagai pupuk organik cair, juga diketahui berpotensi sebagai larvasida nabati karena terdapat senyawa flavonoid, triterpenoid, coumarin, asam coumaric, asam melitotik, dan glukosida stigmastanol yang dapat diidentifikasi dan diisolasi dari berbagai bagian tubuh tanaman Gamal. Tujuan penelitian ini adalah menguji efek larvisidal ekstrak daun Gamal (G. sepium) terhadap larva nyamuk Aedes aegypti. Penelitian dilakukan menggunakan desain eksperimental dengan rancangan Post test only control group design dan Rancangan Acak Lengkap yang terdiri atas 6 kelompok perlakuan. Dua kelompok sebagai kontrol (kontrol positif dan negatif) sedangkan 4 kelompok lainnya mendapat perlakuan pemberian ekstrak daun Gamal (G. sepium) dosis 50 ppm (PI), 150 ppm (P2), 250 ppm (P3), dan 350 ppm (P4). Tidak terjadi mortalitas larva Ae. aegypti dari galur murni setelah pemberian ekstrak daun Gamal, namun mortalitas hanya terjadi pada larva Ae. aegypti kelompok kontrol positif yang berasal dari lapangan. Tidak diketahui LC $_{50}$ dan LC 90 . Sebanyak 13 ekor (52\%) larva Ae. aegypti galur murni tergolong toleran sedangkan sebanyak 19 ekor (76\%) larva Ae. aegypti yang berasal dari lapangan tergolong resisten
\end{abstract}

\begin{abstract}
Gamal leaves (Gliricidia sepium) well known as liquid organic fertilizer, are also known to have potential as vegetable larvicides because there are flavonoids, triterpenoids, coumarin, coumaric acid, mitotic acid, and stigmastanol glucoside which can be identified and isolated from various parts from Gamal. The aim of this study was to examine the larvicidal effect of Gamal (G. sepium) leaf extract against larvae of Aedes aegypti mosquitoes. The study was conducted using an experimental design with a posttest only control group design and a completely randomized design consisting of 6 treatment groups. Two groups as control (positive and negative control), while 4 other groups received treatment of Gamal leaf extract (G. sepium) at doses of 50 ppm (PI), 150 ppm (P2), $250 \mathrm{ppm}$ (P3), and $350 \mathrm{ppm}$ (P4). There was no mortality of larvae Ae. aegypti from pure lines after giving Gamal leaf extract, but mortality only occurred in Ae. aegypti larvae positive control group originating from the field. Unknown LC50 and LC90. A total of 13 (52\%) Ae. aegypti strain classified as tolerant, while as many as 19 (76\%) larvae of Ae. aegypti originating from the field are classified as resistant

blished by Institute for Research and Community Services Universitas Muhammadiyah
\end{abstract} Palangkaraya. This is Open Access article under the CC-BY-SA License (http://creativecommons.org/licenses/by-sa/4.0/). DOI: https://doi.org// 0.33084/jsm.vxix.xxx.

\section{PENDAHULUAN}

Pemberantasan larva Aedes spp. merupakan salah satu bentuk pengendalian vektor dalam upaya pencegahan penyakit. DBD. Pengendalian vektor tergantung pada jenis insektisida yang digunakan. Salah satu jenis insektisida yang sering diaplikasikan sebagai larvasida adalah temefos karena memiliki efektifitas tinggi dalam 
menurunkan jumlah vektor nyamuk, namun dapat menyebabkan resistensi insektisida bagi larva Ae. aegypti bila digunakan secara berulang. Insektisida yang efektif, efisien, ramah lingkungan, dan tidak memberikan efek toksisitas tinggi diperlukan terhadap organisme non target (Astriani \& Widawati, 2016; Tikar et al., 2008).

Penggunaan insektisida sintetis dalam jangka waktu lama dan berskala luas dapat menimbulkan terjadinya resistensi. Berbagai cara dapat dilakukan untuk mengetahui resistensi insektisida, antara lain uji baku WHO dengan impregnated paper, uji molekuler, uji asetilkolin esterase (AChE) dan uji biokima aktivitas enzim alfa atau beta naphythyl acetate (Enzim esterase). Uji biokimiawi enzim esterase memiliki keunggulan dalam mengetahui mekanisme resistensi pada serangga secara individu berdasarkan kuantifikasi enzim yang bertanggung jawab pada proses resistensi. Uji ini sangat cepat dapat menginformasikan status kerentanan yang diperoleh sehingga dapat membantu dalam meramalkan adanya cross resistant (Astuti \& Hastuti, 2017; Hematpoor et al., 2016; Soenjono, 20II).

Penggunaan insektisida nabati saat ini dianggap sebagai alternatif baru dalam penurunan jumlah penyakit yang ditimbulkan oleh vektor nyamuk karena bersifat ramah lingkungan, mudah diperoleh, dan terbukti efektif dalam membunuh vektor nyamuk. Insektisida nabati dapat diperoleh melalui pemanfaatan tanaman di lingkungan sekitar pemukiman yang berpotensi untuk membunuh stadium larva maupun nyamuk dewasa Ae. aegypti. Pembuatan ekstrak tanaman untuk dijadikan larvasida menjadi salah satu bentuk pemanfaatan tanaman sebagai insektisida (Astriani \& Widawati, 2016; Boesri et al., 2015)

Daun Gamal (Gliricidia sepium) merupakan jenis tanaman Leguminosae yang tumbuh cepat di daerah kering, namun efektif dimanfaatkan sebagai pupuk organik cair (Mayasari et al., 2012). Tanaman ini juga diketahui berpotensi sebagai larvasida nabati. Berbagai senyawa yang ditemukan pada tanaman Gamal, antara lain flavonoid, triterpenoid, coumarin, asam coumaric, asam melitotik, dan glukosida stigmastanol yang dapat diidentifikasi dan diisolasi dari berbagai bagian tubuh tanaman Gamal. Selain sebagai larvasida, daun Gamal dimanfaatkan oleh masyarakat India sebagai repelen, antifungi, dan anti bakteri (Reddy \& Jose, 2010). Pelarut etanol, iso-propanol, dan aseton pada ekstrak daun Gamal (G. sepium) terbukti aktif menyerang Ae. aegypti sedangkan pelarut toluen menunjukkan pengaruh negatif terhadap Ae. aegypti (Krishnaveni et al., 2015).

Ekstrak daun Gamal (G. sepium) terbukti memiliki efek lethal terhadap seluruh larva Anopheles setelah 6 jam pengamatan pada konsentrasi 0, 25, 50, 100, 150, 200, dan 250 ppm. Hasil analisis probit LC $_{50}$ sebesar 70,68 Ppm/ 6 jam. Tidak ditemukan adanya efek lethal pada organisme non target (Mathew et al., 20I5).

Ekstrak etanol G. sepium menyebabkan efek lethal larva Anopheles stephensi pada konsentrasi 250 ppm (96,0 \pm 2,4\%). LC LC $_{50}$ sebesar $121,79 \mathrm{ppm}$ sedangkan $\mathrm{LC}_{90}$ sebesar 23I,98 ppm. Ekstrak etanol G. sepium diketahui efektif dalam membunuh telur, larva, dan pupa An. stephensi (Krishnappa et al., 20I2).

Tujuan penelitian ini adalah menguji efek larvisidal ekstrak daun Gamal (Gliricidia sepium) terhadap larva nyamuk Aedes aegypti.

\section{METODOLOGI}

Penelitian dilaksanakan pada bulan Januari-Maret 202I. Pembuatan ekstrak daun Gamal dilaksanakan di Laboratorium Farmakologi Farmakologi Fakultas Farmasi Universitas Muhammadiyah Purwokerto sedangkan uji efek larvasidal daun Gamal (G. sepium) terhadap larva Ae. aegypti dilaksanakan di Balitbangkes Kemenkes Kelas I Banjarnegara.

Penelitian dilakukan menggunakan desain eksperimental dengan rancangan Post test only control group design dan Rancangan Acak Lengkap terdiri atas enam kelompok perlakuan, antara lain 
K + (Kontrol positif): Larva Aedes aegypti diujikan dengan temefos I \%

K- (Kontrol negatif) : Larva Ae. aegypti diujikan dengan ekstrak daun Gamal 0 Ppm

PI : Larva Ae. aegypti diujikan dengan ekstrak daun Gamal 50 ppm

P2 : Larva Ae. aegypti diujikan dengan ekstrak daun Gamal 150 ppm

P3 : Larva Ae. aegypti diujikan dengan ekstrak daun Gamal 250 ppm

P4 : Larva Ae. aegypti diujikan dengan ekstrak daun Gamal 350 ppm

\section{Pengambilan dan Pengolahan Sampel}

Sampel daun Gamal (G. sepium) diperoleh dari Kecamatan Rembang, Kabupaten Purbalingga dan banyak dijumpai di daerah tersebut. Sampel dibersihkan dari kotoran yang menempel, dikeringkan dengan diangin-anginkan dan disimpan dalam lemari pengering. Sampel diblender hingga menjadi serbuk, disimpan dalam wadah dan siap untuk dilakukan proses ekstraksi (Utami et al., 2016).

\section{Preparasi Ekstrak Daun Gamal}

Daun Gamal (G. sepium) kering selanjutnya dibuat sediaan bubuk. Pembuatan ekstrak dibuat dengan cara mencampurkan 40gram bubuk daun Gamal kemudian dilarutkan dalam etanol 96\%, diekstraksi dengan cara maserasi hingga mendapatkan konsentrasi 100\% kemudian diinkubasi selama 2x 24 jam. Ekstrak disaring dengan kertas saring Whatman no. 42, dipekatkan secara vakum dengan vacuum rotary evaporator kemudian diencerkan dengan aquadest sehingga mendapatkan konsentrasi ekstrak sebesar 0,150, 250, dan 350 ppm dalam volume 200 mL. Ekstrak disimpan dalam ruang gelap selama 24 jam (Utami et al., 2016).

\section{Pemeliharaan Larva Nyamuk}

Telur Aedes aegypti yang diperoleh dari Sekolah IImu dan Teknologi Hayati Institut Teknologi Bandung (galur murni) dan Balitbangkes Kemenkes Kelas I Banjarnegara (lapangan) diletakkan dalam nampan plastik berisi air untuk pemeliharaan larva. Telur menetas menjadi larva dalam waktu I-2 hari. Larva instar I berkembang menjadi larva instar III selama 3-5 hari. Larva diberi pakan pellet ikan atau dog food selama masa pemeliharaan. Larva instar III dipindahkan ke dalam paper cup untuk dilakukan uji aktivitas biolarvasida (Cania \& Setyaningrum, 2013; Krishnaveni et al., 2015).

\section{Uji Larvasida Ekstrak daun Gamal (Gliricidia sepium)}

Uji larvasida dilakukan dengan memasukkan masingmasing konsentrasi uji ke dalam paper cup. Larva Aedes aegypti instar III sebanyak 25 ekor dimasukkan ke dalam paper cup menggunakan pipet tetes. Mortalitas diamati pada I jam, 2 jam, 4 jam, dan 8 jam. Dilakukan perhitungan mortalitas larva Aedes aegypti untuk mengetahui dosis efektif $L_{50}$ dan $L C_{90}$. Berikut ini perhitungan mortalitas terkoreksi dan persentase mortalitas (Cania \& Setyaningrum, 2013; Krishnaveni et al., 2015).

Mortalitas terkoreksi $=$

Mortalitas kelompok perlakuan-mortalitas kelompok kontrol 100-mortalitas kontrol

$\times 100$

Persentase mortalitas $(\%)=\frac{\text { Jumlah larva mati }}{\text { jumlah larva terintroduksi }} \times$ $100 \%$

\section{Uji Aktitivitas Enzim Esterase Non Spesifik}

Larva nyamuk instar IV digerus individual untuk dibuat homogenate kemudian dilarutkan dengan $0,5 \mathrm{~mL}$ larutan Phosphate Buffer Saline (PBS) 0,02 M, pH = 7 . Homogenat dipindahkan ke dalam microplate kemudian ditambahkan sebanyak $50 \mu \mathrm{L}$ substrat $\alpha$ naftil asetat dalam aseton (6 g/L) dicampur dengan $50 \mathrm{~mL}$ buffer phosphate $(0,02 \mathrm{M}$; $\mathrm{pH}=7)$ dan dibiarkan selama 60 
detik. Setiap microplate selanjutnya ditambahkan sebanyak $50 \mu \mathrm{L}$ copling reagent berupa $150 \mathrm{mg}$ garam Fast Blue B (o-dianisidine, tetrazotized; sigma) dalam $15 \mathrm{~mL}$ aquadest dan $35 \mathrm{~mL}$ aquous (5\%;wlv) sodium dodecyl sulphate (Sigma B) selama 10 menit. Terjadi perubahan warna merah menjadi biru setelah inkubasi 10 menit. Ditambahkan sebanyak $50 \mu \mathrm{L}$ asam asetat $10 \%$ ke dalam masing-masing microplate yang berisi homogenate. Adanya intensitas warna menunjukkan adanya aktivitas enzim esterase non spesifik dan tingkatnnya dapat dibedakan secara visual. Aktivitas enzim secara kuantitatif dibaca melalui ELISA reader dengan Panjang gelombang $450 \mathrm{~nm}$. Status resistensi dilihat dari hasil absorbansi, jika $\mathrm{AV}<0,700=$ rentan (SS), AV $0,700-0,900=$ toleran (SR), dan AV >0,900 = resisten (RR) (Astuti \& Hastuti, 2017; Suryawanshi et al., 2015).

\section{Analisis Data}

I. Data mortalitas larva Aedes aegypti dianalisis dengan One Way ANOVA apabila data berdistribusi normal dan variansinya sama. Dilanjutkan dengan uji Bonferroni apabila beda nyata signifikan. Uji Kruskall-Wallis digunakan sebagai uji alternatif.

2. Analisis Probit digunakan untuk menganalisis LC $_{50}$ dan $\mathrm{LC}_{90}$
3. Aktivitas Enzim Esterase Non Spesifik dianalisis dengan Pearson Chi Square.

\section{HASIL DAN PEMBAHASAN}

Mortalitas larva Ae. aegypti lapangan hanya terjadi pada kelompok kontrol positif setelah I jam, 2 jam, dan 4 jam pemberian temefos $1 \%$ sedangkan setelah 8 jam tidak ditemukan mortalitas larva. Tidak ada mortalitas larva Ae. aegypti setelah pemberian ekstrak daun gamal 0 ppm (K-), 50 ppm (PI), I50 ppm (P2), 250 Ppm (P3), dan 350 ppm (P4) pada I jam, 2 jam, 4 jam, dan 8 jam. Mortalitas larva Ae. aegypti galur murni hanya terjadi pada kelompok kontrol positif setelah I jam pemberian temefos $1 \%$ sedangkan kelompok lainnya tidak terjadi mortalitas. Guna membuktikan efektivitas ekstrak daun gamal sebagai larvasida Ae. aegypti, dilakukan pengulangan dengan dosis 5 kali lipat. Hasil pengulangan juga menunjukkan tidak adanya mortalitas larva. Tidak ditemukan LC50 dan LC90 dalam penelitian ini. Mortalitas larva Ae. aegypti lapangan setelah pemberian ekstrak daun Gamal (G. sepium) disajikan pada Tabel I sedangkan mortalitas larva Ae. aegypti galur murni disajikan pada Tabel 2.

Tabel I. Mortalitas Larva Aedes aegypti Lapangan Setelah Pemberian Ekstrak Daun Gamal (G. sepium)

\begin{tabular}{lcccc}
\hline \multicolumn{1}{r}{ Perlakuan } & \multicolumn{3}{c}{ Mortalitas (\%) } \\
\cline { 2 - 5 } & I jam & 2 jam & 4 jam & 8 jam \\
\hline K+ (temefos I\%) & 64 & 97,3 & 100 & 0 \\
K- (ekstrak daun gamal 0 ppm) & 0 & 0 & 0 & 0 \\
PI (ekstrak daun gamal 50 ppm) & 0 & 0 & 0 & 0 \\
P2 (ekstrak daun gamal I50 Ppm) & 0 & 0 & 0 & 0 \\
P3 (ekstrak daun gamal 250 PPm) & 0 & 0 & 0 & 0 \\
P4 (ekstrak daun gamal 350 ppm) & 0 & 0 & 0 & 0
\end{tabular}

Tabel 2. Mortalitas Larva Aedes aegypti Galur Murni Setelah Pemberian Ekstrak Daun Gamal (G. sepium)

\begin{tabular}{lcccc}
\multicolumn{1}{r}{ Perlakuan } & \multicolumn{3}{c}{ Mortalitas (\%) } \\
\cline { 2 - 5 } & I jam & 2 jam & 4 jam & 0 \\
\hline K+ (temefos 1\%) & 100 & 0 & 0 & 0 \\
K- (ekstrak daun gamal 0 ppm) & 0 & 0 & 0 & 0 \\
PI (ekstrak daun gamal 50 ppm) & 0 & 0 & 0 & 0 \\
P2 (ekstrak daun gamal 150 ppm) & 0 & 0 & 0 & 0
\end{tabular}


P4 (ekstrak daun gamal 350 ppm)

Sebanyak 13 ekor (52\%) larva Ae. aegypti galur murni tergolong toleran sedangkan sebanyak 19 ekor (76\%) larva Ae. aegypti yang berasal dari lapangan tergolong resisten. Sebanyak 25 ekor (50\%) dari 50 ekor larva yang diujikan mengalami resistensi. Hasil Analisis Pearson Chi Square $\left(X^{2}\right)$ menunjukkan adanya
0 hubungan antara jenis sampel larva Ae. aegypti dengan status resistensi $(p<0,05)$. Larva Ae. aegypti yang berasal dari lapangan terbukti banyak yang mengalami resistensi. Hasil uji aktivitas enzim esterase non spesifik disajikan pada Tabel 3.

Tabel 4.2. Hasil Uji Aktivitas Enzim Esterase Non Spesifik

\begin{tabular}{lccc}
\hline \multicolumn{1}{c}{$\begin{array}{c}\text { Sampel Larva Ae. } \\
\text { aegypti }\end{array}$} & Susceptible & Toleran & Resisten \\
\cline { 2 - 4 } Murni & $6(24 \%)$ & $13(52 \%)$ & $6(24 \%)$ \\
Lapangan & $1(4 \%)$ & $5(20 \%)$ & $19(76 \%)$ \\
\hline Total & $7(14 \%)$ & $18(36 \%)$ & $25(50 \%)$ \\
\hline
\end{tabular}

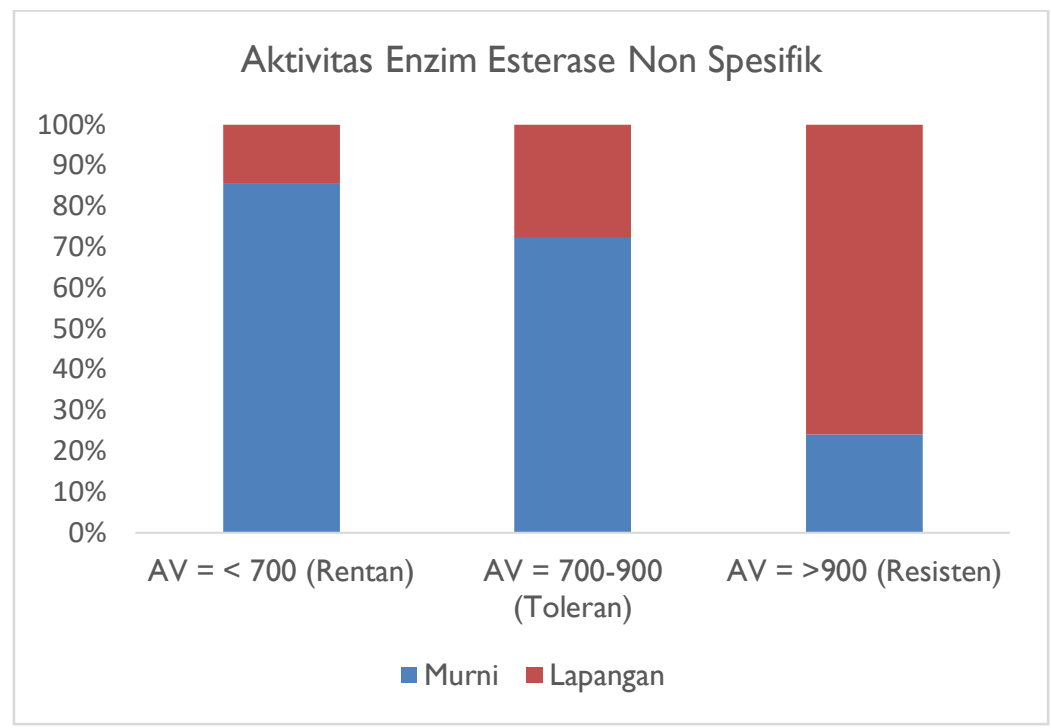

Gambar I. Aktivitas Enzim Esterase Non Spesifik

Mortalitas larva Ae. aegypti dalam penelitian ini yang hanya terjadi setelah pemberian temefos, namun tidak terjadi mortalitas setelah pemberian ekstrak daun Gamal (G. sepium) berbanding terbalik dengan hasil penelitian Mathew et al. yang menunjukkan bahwa mortalitas larva Ae. aegypti setelah pemberian ekstrak daun gamal konsentrasi 150 ppm (70,68\%), 200 ppm (84,00\%), dan 200 ppm (93,00\%). Efek lethal tidak terlihat setelah paparan I jam pada seluruh konsentrasi, namun terlihat setelah paparan 3-6 jam. LC $_{50}$ diketahui sebesar 70, 68 ppm selama 6 jam (Mathew et al., 20I5).
Selaras dengan hasil penelitian George yang juga menunjukkan tidak ada mortalitas larva instar III dan IV Ae. aegypti setelah pemberian ekstrak aseton maupun ekstrak methanol daun Gamal (G. sepium) pada konsentrasi $0,1 \mathrm{mg} / \mathrm{mL}, 0,2 \mathrm{mg} / \mathrm{mL}$, dan $0,4 \mathrm{mg} / \mathrm{mL}$ (George, 2018).

Studi yang dilakukan oleh Corpuz \& Savella menunjukkan bahwa ekstrak etanol daun G. sepium 0 $\mathrm{mg} / \mathrm{mL}$ dan $25 \mathrm{mg} / \mathrm{mL}$ diketahui tidak efektif, $50 \mathrm{mg} / \mathrm{mL}$ sedikit efektif, $75 \mathrm{mg} / \mathrm{mL}$ cukup efektif, dan $100 \mathrm{mg} / \mathrm{mL}$ efektif dalam menimbulkan mortalitas larva Ae. aegypti. Malathion sangat efektif dalam menyebabkan mortalitas larva Ae. aegypti. Mortalitas paling tinggi larva Ae. 
aegypti setelah 24 jam pemberian ekstrak daun $G$. sepium konsentrasi $100 \mathrm{mg} / \mathrm{mL}$ sebanyak $75,56 \%$ sedangkan setelah 48 jam sebanyak 100\%. Adanya kombinasi antara ekstrak daun Gamal dan daun pepaya diketahui menyebabkan mortalitas paling tinggi dibandingkan ekstrak daun Gamal saja maupun ekstrak daun pepaya saja. Konsentrasi $100 \mathrm{mg} / \mathrm{mL}$ kombinasi ekstrak daun gamal dan daun pepaya mampu menyebabkan mortalitas hingga 96, 67\% setelah pajanan selama 24 jam dan $100 \%$ setelah pajanan 48 jam (Corpuz \& Savella, 2019).

Ekstrak etanol G. sepium dosis 250 ppm terbukti menyebabkan mortalitas paling tinggi larva instar III Anopheles stephensi yang baru menetas 0-6 jam sebanyak $96,0 \pm 2,4 \%$. Persentase tersebut lebih tinggi bila dibandingkan ekstrak etil asetat $G$. sepium dosis 250 ppm dengan mortalitas sebanyak 92,2 \pm 1,2 \%. Persentase mortalitas larva An. stephensi setelah pemberian ekstrak etanol G. sepium pada kelompok kontrol, 50 ppm, 100 ppm, 150 ppm, 200 ppm, dan 250 ppm lebih tinggi daripada ekstrak etil asetat (Krishnappa et al., 2012).

Mortalitas larva Ae. aegypti instar II -IV setelah pemberian ekstrak minyak $G$. sepium dengan pelarut methanol diketahui lebih rendah bila dibandingkan dengan ekstrak sirsak (Annona squamosa), namun berbanding terbalik dengan mortalitas larva setelah pemberian ektrak minyak $G$. sepium dengan pelarut hexane yang cenderung menyebabkan mortalitas lebih tinggi bila dibandingkan dengan ekstrak $A$. squamosa dengan pelarut hexane. LC $_{50}$ paling tinggi setelah pemberian ekstrak $A$. squamosa dengan pelarut hexane pada larva instar II (77,62 ppm), instar III (95,40 ppm), instar IV (I28,82 Ppm). LC 90 paling tinggi setelah pemberian ekstrak minyak $G$. sepium dengan pelarut hexane pada larva instar II (I34,89 Ppm), instar III (346,73 Ppm), instar IV (457,08 Ppm). Ekstrak methanol $G$. sepium memiliki efektifitas tinggi menyebabkan mortalitas larva Ae. aegypti bila dibandingkan dengan ekstrak minyak G. Sepium (Goyal et al., 2019).

Minyak esensial daun $G$. sepium dapat menimbulkan mortalitas paling tinggi pada konsentrasi $250 \mathrm{mg} / \mathrm{mL}$ sejak 0 jam. Konsentrasi $10 \mathrm{mg} / \mathrm{mL}$ dapat menimbulkan mortalitas setelah 24 jam paparan. Semakin tinggi konsentrasi minyak esensial daun $G$. sepium, maka semakin cepat dalam membunuh larva Aedes aegypti (Umadevi \& Jaleel, 2020). Hal ini dikarenakan methanol merupakan pelarut polar yang efektif dibandingkan aseton sehingga banyak senyawa fitokimia aktif yang mudah larut dalam methanol (George, 2018).

Resistensi terjadi akibat paparan insektisida terhadap vektor yang dipengaruhi oleh beberapa faktor, antara lain cara aplikasi, dosis, dan cakupan intervensi. Adanya peningkatan aktivitas total enzim menyebabkan senyawa yang sebelumnya bersifat toksik menjadi tidak toksik. Terjadinya mutasi pada enzim atau bertambahnya ekspresi enzim menyebabkan meningkatnya aktivitas enzim sehingga terjadi resistensi terhadap beberapa senyawa insektisida, meliputi organofosfat, karbamat, dan piretroid (Astuti \& Hastuti, 2017).

Enzim esterase diketahui berperan dalam mekanisme resistensi terhadap insektisida golongan organofosfat. Enzim ini akan mengkatalisis reaksi hidrolisis komponen alifatik, ester aromatic, kolin, dan organofosfor. Terdeteksinya resistensi disebabkan oleh terjadinya peningkatan aktivitas enzim esterase ketika menghentikan komponen insektisida untuk mencapai targetnya. Terjadinya toleran terhadap insektisida disebabkan karena rendahnya aktivitas enzim esterase sehingga kemampuan untuk menghidrolisis karboksilester juga rendah dan berdampak toksik bagi nyamuk (Mulyaningsih et al., 2017; Tomia et al., 2019)

\section{KESIMPULAN}

Tidak terjadi mortalitas larva Aedes aegypti galur murni setelah pemberian ekstrak daun Gamal (G. sepium), 
namun mortalitas hanya terjadi pada kelompok kontrol positif larva Ae. aegypti dari lapangan. Daun Gamal (G. sepium) tidak dapat dijadikan larvasida nabati dalam penelitian ini. Tidak dapat diketahui LC $_{50}$ dan LC $_{90}$ karena tidak ada mortalitas larva Ae. aegypti. Sebanyak 13 ekor (52\%) larva Ae. aegypti galur murni tergolong toleran sedangkan sebanyak 19 ekor (76\%) larva Ae. aegypti yang berasal dari lapangan tergolong resisten.

Perlu dilakukan peningkatan program eliminasi Demam Berdarah Dengue karena banyaknya larva yang mengalami resistensi. Perlu dilakukan penelitian serupa dengan ekstrak yang berbeda, seperti daun sirsak, daun pepaya, dan lain sebagainya. Perlu dipertimbangkan penggunaan insektisida nabati sebagai alternatif karena daya mematikan larva tidak terlalu kuat

\section{UCAPAN TERIMA KASIH}

Terima kasih kepada Program Pascasarjana Magister Ilmu Biomedis, Fakultas Kedokteran, Universitas Jendral Soedirman Purwokerto, Sekolah Ilmu dan Teknologi Hayati Institut Teknologi Bandung, Balitbangkes Kemenkes Kelas I Banjarnegara, dan Laboratorium Farmakologi Farmakologi Fakultas Farmasi Universitas Muhammadiyah Purwokerto yang telah mendukung penelitian ini.

\section{REFERENSI}

I. Astriani, Y., \& Widawati, M. (2016). Potensi Tanaman di Indonesia Sebagai Larvasida Alami untuk Aedes aegypti. SPIRAKEL, 8(2), 37-46.

2. Tikar, S. N., Mendki, M. J., Chandel, K., Parashar, B. D., \& Prakash, S. (2008). Susceptibility of immature stages of Aedes (Stegomyia) aegypti; vector of dengue and chikungunya to insecticides from India. Parasitology Research, I02(5), 907-913. https://doi.org//0.1007/s00436-007-0848-5

3. Astuti, F. D., \& Hastuti, I. (20I7). Deteksi Resistensi Pada Aedes aegypti Dengan Pengujian Enzim Esterase Non Spesifik. The 5th URECOL Proceeding, 388-391.
4. Hematpoor, A., Liew, S. Y., Chong, W. L., Azirun, M. S., Lee, V. S., \& Awang, K. (2016). Inhibition and larvicidal activity of phenylpropanoids from piper sarmentosum on acetylcholinesterase against mosquito vectors and their binding mode of interaction. PLOS ONE, II(5), I-27. https://doi.org//0.137I/journal.pone.0155265

5. Soenjono, S. J. (20I I). Status Kerentanan Nyamuk Aedes sp.(Diptera: Culicidae) Terhadap Malation dan Aktivitas Enzim Esterase Non Spesifik Di Wilayah Kerja Kantor Kesehatan Pelabuhan Bandar Udara Sam Ratulangi Manado. JKL, I(I), I6. https://www.neliti.com/publications/ I04875/statuskerentanan-nyamuk-aedes-sp-dipteraculicidaeterhadap-malation-dan-aktivit

6. Boesri, H., Heriyanto, B., Handayani, S. W., \& Suwaryono, T. (20I5). Uji Toksisitas Beberapa Ekstrak Tanaman Terhadap Larva Aedes aegypti Vektor Demam Berdarah Dengue. Vektora: Jurnal Vektor Dan Reservoir Penyakit, 7(1), 29-38. https://doi.org// 0.22435/vk.v7il.4258.29-38

7. Mayasari, D., Purbajanti, E. ., \& Sutarno. (20/2). Kualitas Hijauan Gamal (Gliricidia sepium) Yang Diberi Pupuk Organik Cair (POC) Dengan Dosis Berbeda. Animal Agriculture Journal, I(2), 293-30I.

8. Reddy, L. J., \& Jose, B. (2010). Evaluation of Antibacterial Activity of The Bark, Flower, and Leaf Extracts of Gliricidia sepium From South India. International Journal of Current Pharmaceutical Research, 2(3), 18-20.7645(I2)60I24-2

9. Krishnaveni, K. V, Nayaki, R. T., \& Balasubramanian, M. (20/5). Effect of Gliricidia sepium leaves extracts on Aedes aegypti: Larvicidal activity. Journal of Phytology, 7, 26-31. https://doi.org/10.1907//ip.2015.v7.2898

10. Mathew, J. J., Vazhacharickal, P. J., Sajeshkumar, N. K.,\& Sunil, J. (20I5). Larvicidal Activity of Gliricidia sepium Leaf Extracts on Mosquito Larvae and Its Lethal Effect on NonTargeted Organisms. CIBTech Journal of Biotechnology, 4(2), 13-19.

II. Krishnappa, K., Dhanasekaran, S., \& Elumalai, K. (20I2). Larvicidal , ovicidal and pupicidal activities of Gliricidia sepium ( Jacq .) (Leguminosae ) against the malarial vector, Anopheles stephensi Liston ( Culicidae : Diptera ). Asian Pacific Journal of Tropical Medicine, 5(8), 598-604. https://doi.org/10.1016/S1995-

12. Utami, W. W., Ahmad, A. R., \& Malik, A. (20|6). Uji Aktivitas Larvasida Ekstrak Daun Jarak Kepyar (Ricinus communis L.) Terhadap Larva Nyamuk 
Aedes aegypti. Jurnal Fitofarmaka Indonesia, 3(I), $|4|-\mid 45$.

13. Cania, E., \& Setyaningrum, E. (20I3). Uji Efektivitas Larvasida Ekstrak Daun Legundi (Vitex trifolia) Terhadap Larva Aedes aegypti. Medical Journal of Lampung University, 2(4), 52-60.

14. Suryawanshi, R. K., Chandrashekhar, D., Borase, H. P., Narkhede, C. P., Salunke, B. K., \& Patil, S. V. (2015). Mosquito larvicidal and pupaecidal potential of prodigiosin from Serratia marcescens and understanding its mechanism of action. Pesticide Biochemistry and Physiology, I-I6. https://doi.org/10.1016/j.pestbp.2015.01.018

15. Corpuz, A. V, \& Savella, M. R. (2019). Larvicidal Activity of Papaya (Carica papaya) and Madre de Cacao (Gliricidia sepium) Leaf Ex-tracts Against Aedes aegypti. International Journal of Scientific \& Engineering Research, 10(10), 1710-1716.

16. Goyal, M., Shinde, L., \& Bayas, R. (2019). Study of chemical composition and larvicidal efficacy of secondary metabolites from aromatic phytoextracts against dengue vector: Aedes aegypti (Linn) (Diptera: Culicidae). International Journal of Mosquito Research, 6(I), 26-33.

17. Umadevi, \& Jaleel, A. (2020). Larvicidal Activity of Essential Oil of Gliricidia Sepium Leaf. International Journal of Current Pharmaceutical Research, 12(1), 26-27.

https://doi.org//0.22159/ijcpr.2020v/2il.36827

18. George, S. (20/8). Larvicidal Activity of Various Extracts of Selected Plants Against the Dengue Vector Larvae. International Journal of Current Pharmaceutical Review and Research, 9(5), 67-70.

19. Mulyaningsih, B., Umniyati, S. R., \& Hadianto, T. (2017). Detection of Nonspesific Esterase activity in Organophosphate Resistant Strain of Aedes albopictus Skuse (Diptera: Culicidae) Larvae in Yogyakarta, Indonesia. Southeast Asian J Trop Med Public Health, 48(3), 552-560.

20. Tomia, A., Hadi, U. K., \& Retnani, E. B. (2019). The Detection of Aedes Aegypti Mosquito Resistance With Biochemical Test Based on Nonspecific Esterase Enzyme Activity and Monooksigenase Enzyme in Ternate City. Journal of Physics: Conference Series, 1364(2019), I-6. https://doi.org// 0.1088//742-6596/I364/I/0I2014 